\title{
Corporate Governance: the way forward
}

\author{
Oscar van Leeuwen en Philip Wallage
}

Twintig jaar geleden, om precies te zijn op 25 juni 1997, verscheen het rapport van de eerste Nederlandse Commissie Corporate Governance onder voorzitterschap van Jaap Peters met de titel "Aanbevelingen inzake Corporate Governance in Nederland”. In 2003 gevolgd door "De Nederlandse corporate governance code "Beginselen van deugdelijk ondernemingsbestuur en best practice bepalingen.” Deze Code, vernoemd naar de voorzitter van de commissie Morris Tabaksblat, werd bij Besluit van 23 december 2004 in de wet verankerd (Stb. 2004, nr. 747). Sindsdien moeten beursfondsen in het bestuursverslag mededeling doen over de naleving van de principes en best practice-bepalingen. Recentelijk is de code onder leiding van Jaap van Manen geactualiseerd en op 8 december 2016 gepubliceerd. De belangrijkste inhoudelijke wijzigingen betreffen onder andere een focus op langetermijnwaardecreatie en aandacht voor risicobeheersing, cultuur en beloning.

Het corporate governance-domein kenmerkt zich door de constante zoektocht naar een balans tussen de belangen die verschillende stakeholders in een onderneming hebben.

Een voorbeeld is de doorlopende discussie over de hoogte van beloningen van bestuurders en commissarissen. Voorstanders van verhoging wijzen op de noodzaak de beste 'agenten' aan te trekken en hen te prikkelen het belang van de 'principalen' na te streven. Tegenstanders wijzen op de wanverhouding tussen de beloning van de top en die van de werkvloer en het ontbreken van een duidelijke relatie tussen de beloning en prestaties.

Daarnaast is een trend waarneembaar dat activistische aandeelhouders Nederlandse beursvennootschappen willen overnemen. Deze aandeelhouders zouden uit zijn op kortetermijnwinst en geen oog hebben voor de lange termijn. Deze kritiek komt steeds naar voren bij overnamegeruchten, zoals in geval van TCI dat ABN AMRO onder druk zette en Centaurus Capital en Paulson Capital die Stork wilden opsplitsen. Ook de recente overnamepogingen van Unilever en van AKZO zijn hiervan voorbeelden. Als gevolg hiervan is door minister Kamp (EZ) het voorstel gedaan om bedrijven een wettelijke bedenktijd te geven waarin ze zich over een overnamebod kunnen beraden (NRC, 20 mei 2017). Voorstanders van een wettelijke bedenktijd menen op deze wijze de kortetermijndruk weg te kunnen nemen, terwijl tegenstanders van mening zijn dat de 'invisible hand' van
Adam Smith zijn werk behoort te doen. Tenslotte zijn er periodiek calamiteiten als gevolg van mismanagement en fraude die de noodzaak van goed risicomanagement bevestigen. Het is dan ook niet verwonderlijk dat de Corporate Governance Code 2016 het thema risicomanagement, waaronder de noodzaak van een effectieve internal audit-functie, sterk benadrukt.

Vanzelfsprekend zijn de ontwikkelingen in corporate governance ook voor accountants van groot belang. Vandaar dat in de nieuwe eindtermen voor de accountantsopleiding de nodige aandacht wordt besteed aan corporate governance. De desbetreffende eindtermen, vastgesteld door de Commissie Eindtermen Accountantsopleiding (CEA), luiden (per vakgebied weergegeven) zoals aangegeven in het kader op pag. 123.

Alle reden dus om in dit themanummer uitgebreid aandacht te besteden aan Corporate Governance en de aangepaste Code! Wij geven een kort overzicht van de onderwerpen die aan de orde komen.

In de eerste bijdrage van dit themanummer gaat Jaap van Manen in zijn functie als voorzitter van de Monitoring Commissie Corporate Governance in op de belangrijkste veranderingen in de Code en noemt de belangrijkste motieven hiertoe.

In het tweede artikel beschrijven Myrtle Grondhuis en Harm-Jan de Kluiver de ontwikkeling van de Corporate Governance Code en haar juridische betekenis. Dit artikel geeft op hoofdlijnen een overzicht van de geschiedenis, werking en structuur van Corporate Governance, en meer specifiek de Code, in Nederland. Voor wat betreft de werking en structuur van de Code, wordt daarbij aandacht besteed aan het type beursondernemingen dat de Codevoorschriften behoort toe te passen, de wijze waarop de naleving ervan in de praktijk vorm krijgt en de status die de Nederlandse rechtspraak aan de Code toedicht.

In de derde bijdrage staan wij stil bij de interne auditfunctie. Hierbij betrekken wij de bevindingen van enkele recente onderzoeken naar de relatie tussen de rol van de interne auditfunctie en het functioneren van de internal governance. Wij constateren dat de aangehaalde onderzoeksresultaten slechts op beperkte en indirecte wijze in de Corporate Governance Code 2016 verwerkt zijn. De Corporate Governance Code 2016 besteedt overigens beduidend meer aandacht aan de rol en positie van de interne auditfunctie dan voorgaande codes. 


\section{Assurance}

de rol van de accountant binnen het systeem van corporate governance samen te vatten respectievelijk te beoordelen, in het bijzonder de relatie met de organen belast met governance en relevante externe toezichthouders.

\section{Internal Control/Accounting Information Systems}

vanuit het perspectief van corporate governance de werking van het systeem van interne controle met betrekking tot financiële informatie en de eventuele risico's en gevolgen te beschrijven respectievelijk te evalueren.

\section{Strategie, Leiderschap \& Organisatie}

Het governancesysteem van een onderneming te analyseren aan de hand van beleid, wet- en regelgeving en code.

\section{Financiering}

vanuit financieringsperspectief op basis van de meest gangbare theorieën op het gebied van corporate governance de werking van de huidige corporate governance structuur van een onderneming te typeren respectievelijk hierover een oordeel te geven.

Recht

de belangrijkste elementen van het ondernemingsrecht te onderkennen waaronder:

- rechtsvormen waarin ondernemingen gedreven worden;

- de verantwoordelijkheden, bevoegdheden en aansprakelijkheden van de organen van de entiteit;

- de (inter)nationale ontwikkelingen op het terrein van corporate governance;

- de juridische aspecten van IT;

teneinde de juridische gevolgen en risico's van feiten en gebeurtenissen voor de onderneming te beschrijven en hierover te rapporteren.

In het volgende artikel behandelt Jim Emanuels de achtergrond en betekenis van het 'in control statement' dat volgens een best practice-bepaling in de herziene corporate governance code 2016 door ondernemingen in het bestuursverslag moet worden opgenomen. Hij gaat hierbij in op:

- een aantal wijzigingen ten opzichte van eerdere versies van deze bepaling,

- de relatie met de risico-informatie in het bestuursverslag en

hij bespreekt enkele bijzondere aandachtspunten voor de toepassing in de praktijk.

Arnoud Boot betoogt vervolgens dat ondernemingen ook naar hun eigendomsverhoudingen moeten kijken. In een dynamische, snel veranderende omgeving passen meer nabije aandeelhouders waarmee op continue basis kan worden 'geschakeld'. Hij ziet de bestuurders zelf als de belangrijkste boosdoeners omdat ze onvoldoende voorbereid zijn, maar ook omdat zij onvoldoende tegenwicht bieden tegen de druk van de financiële markten. Het bestuur dient een eigen verhaal te hebben en moet zich niet klem laten zetten. De Raad van Commissarissen is hierbij een belangrijke adviseur die het bestuur op het rechte pad moet houden en de juiste rugdekking moet geven.

Tenslotte schetst Piet Duffhues een nieuwe betaalvorm in geval van buitenlandse overnames van vitale Nederlandse ondernemingen. De voorgestelde oplossing (all equity offer) die in essentie een financiële innovatie van de kapitaalmarkt betreft, zou de overheden uitkomst bieden uit een spagaat die het maken van een verantwoorde keuze inmiddels buitengewoon moeilijk heeft gemaakt.

Prof. dr. Ph. Wallage RA is hoogleraar accountantscontrole aan de Vrije Universiteit en Universiteit van Amsterdam. Prof. dr. O.C. van Leeuwen RA is hoogleraar Bestuurlijke Informatieverzorging aan de Vrije Universiteit en partner bij Improven.

\section{Noten}

1 Geraadpeegd op https://www.nrc.n//nieuws/2017/05/20/kamp-meer-bescherming-tegen-buitenlandse-overnames-a1559753.

2. Geraadpleegd op https://www.ceaweb.n//Documents/Eindtermen\%202016/170118\%20Eindtermen\%20accountantsopleidingen\%202016\%20printv\%20 1.1.pdf?epslanguage=nl. 